\title{
Current Policy Challenges Facing Emerging Markets
}

\author{
Laura Alfaro $^{1} \cdot$ Enrique Mendoza ${ }^{2}$
}

Published online: 8 July 2020

(c) International Monetary Fund 2020

Rising trade barriers, fluctuations in capital flows, financial volatility, and spillovers from industrialized countries' monetary policies create a challenging global environment for emerging markets. These challenges are further complicated by low productivity growth and domestic vulnerabilities in the public sector, financial intermediaries and the private sector. Against this background, the IMF, IMF Economic Review, and the Central Bank of Chile jointly organized a conference on "Current Policy Challenges Facing Emerging Markets." The conference took place in Santiago, Chile on June 24-25, 2019. This volume of the Review features some of the papers presented at the conference. Below, we summarize the key contributions of these papers.

The first paper of this volume focuses on the impact of the rising protectionist sentiments on emerging markets. Emerging Markets and the New Geography of Trade: The Effects of Rising Trade Barriers by Ricardo Reyes-Heroles (Federal Reserve Board), Sharon Traiberman (New York University) and Eva Van Leemput (Federal Reserve Board), serves two main purposes. First, it collects several stylized facts that characterize emerging markets' role in the new geography of trade focusing on differences between advanced economies and emerging markets in trade linkages, production structures, and factor supplies. Second, it builds a dynamic, general equilibrium, quantitative trade model featuring multiple countries, sectors and factors of production. Using the model, the paper shows that heterogeneity in openness, production structure, trade linkages, and factor supplies leads to large differences between the impacts of trade barriers on advanced and emerging markets. Further, the paper finds that variations in both technological comparative advantage and factor supplies play key roles in shaping these differences.

The next paper aims to understand the trend decline in the price of machinery and equipment relative to other prices in advanced and emerging market and developing

Laura Alfaro

lalfaro@hbs.edu

Enrique Mendoza

egme@sas.upenn.edu

1 Harvard Business School, Boston, USA

2 University of Pennsylvania, Philadelphia, USA 
economies over the past three decades. The Price of Capital Goods: A Driver of Investment Under Threat by Weicheng Lian, Natalija Novta, Evgenia Pugacheva, Yannick Timmer and Petia Topalova (all IMF) focuses on the roles of trade integration and productivity. The authors combine cross-country and sector-level tariff data, input and output information, prices and trade flows, and show that the decline in the relative price of tangible tradable capital goods provided a significant impetus to the capital deepening that took place during the same time period. The broadbased decline in the relative price of machinery and equipment, in turn, was driven by the faster productivity growth in the capital-goods-producing sectors relative to the rest of the economy, and deeper trade integration, which induced domestic producers to lower prices and increased their efficiency. The paper's findings suggest an additional channel through which rising trade tensions and sluggish productivity could threaten real investment growth going forward.

Policy setting in emerging markets is partly complicated by the sensitivity of these economies to the policy decisions of advanced economies. The Impact of Industrialized Countries' Monetary Policy on Emerging Economies by Vincenzo Quadrini (University of Southern California, Peking University HSBC Business School and CEPR) shows that following the low interest rate policies adopted by industrialized countries after the 2008 financial crisis, there has been a reduction in capital outflows from emerging countries to industrialized countries. Moreover, emerging countries experienced a decline in output growth bigger than industrialized countries. The paper develops a model capable of replicating this pattern. Contrary to conventional wisdom, it shows that lower interest rates in industrialized countries could have negative macroeconomic consequences for emerging countries even though emerging economies experience increased inflows (or decreased outflows) of capital.

The next paper, Relationship Networks in Banking Around a Sovereign Default and Currency Crisis by Pablo D'Erasmo (Federal Reserve Bank of Philadelphia), Hernán Moscoso Boedo (University of Cincinnati), María Pía Olivero (Drexel University) and Máximo Sangiacomo (Central Bank of Argentina), studies how banks' exposure to a sovereign crisis gets transmitted onto the corporate sector. The paper builds a model characterized by matching frictions in which firms establish (longterm) relationships with banks that are subject to balance sheet disruptions. Credit relationships with banks more exposed to the crisis suffer the most. However, this relationship-level effect may overstate the true cost of the crisis since profitable firms (e.g., exporters after a devaluation) might find it optimal and be able to switch lenders, reducing the negative impact on overall credit and activity. Using linked data on the universe of banks and firms in Argentina during the crisis of 2001, the paper finds evidence largely consistent with the theory.

Moving on to the global financial markets implications of a large emerging market, The Determinants of China's International Portfolio Equity Allocations by Isha Agarwal (University of British Columbia), Grace Weishi Gu (University of California, Santa Cruz) and Eswar Prasad (Cornell University, Brookings Institution, and NBER) analyzes shifts in the structure of China's capital outflows over the past decade. The paper shows that the composition of gross outflows has shifted from accumulation of foreign exchange reserves by the central bank to nonofficial outflows and argues that unlocking the enormous pool of domestic savings could have a significant impact on global financial 
markets as China continues to open up its capital account and as domestic investors look abroad for returns and diversification. The paper then analyzes in detail the allocation patterns of Chinese institutional investors, which constitute the main channel for foreign portfolio investment outflows. The paper shows that Chinese institutional investors underweight developed countries and high-tech sectors in their international portfolio allocations, relative to benchmarks based on market capitalization, but overinvest in high-tech stocks in developed countries. In addition, it finds that in their foreign portfolio allocations, Chinese institutional investors overweight sectors in which China has a comparative disadvantage. Moreover, Chinese institutional investors concentrate such investments in countries that have higher relative comparative advantage in those sectors. Diversification and information advantages related to foreign imports to China seem to influence patterns of foreign portfolio allocations, while yield-seeking and learning motives do not.

The Policy Corner section features Revisiting Exchange Rate Rules by Kathryn Dominguez (University of Michigan). This paper tackles the question of what distinguishes foreign exchange interventions that are stabilizing from those that are manipulative. In the current no-official-agreed-upon rules environment, any country that intervenes and builds up bilateral trade surpluses opens itself to charges of currency manipulation. Emerging economies are especially susceptible because many of them rely on exchangerate stabilization policies to offset external shocks and facilitate trade. This paper proposes an approach to setting international exchange rate policy rules that discourage currency manipulation as well as spurious allegations of manipulation. It examines how intervention operations work and demonstrates how counterfactual matching techniques can be used to test for causal links between intervention policies and exchange rate movements.

We hope that you will enjoy reading this issue. The topics covered by the papers span several of the most important policy threats to emerging markets. Protectionism, policy spillovers from advanced economies, excessive borrowing, emerging-market sovereign default, in a backdrop of low productivity growth, all have the potential to cause severe disruption, while the rise of China poses new opportunities and challenges to policy management. The authors combine state-of-the-art theory and empirics to elucidate new insights.

We are confident that these papers will be very useful references for those interested in the international economic and policy concerns related to emerging markets. We thank all the authors for their interesting contributions and all the discussants for their greatly helpful comments. We are also grateful to several referees for insightful comments and rapid service. Finally, our gratitude goes to the Central Bank of Chile and the IMF for hosting and organizing the conference, to Tracey Lookadoo for her invaluable help throughout the entire process, and to Linda Tesar, Emine Boz, and the IMFER for giving us the possibility of putting together this issue.

Laura Alfaro and Enrique Mendoza

Guest Editors, IMF Economic Review

Publisher's Note Springer Nature remains neutral with regard to jurisdictional claims in published maps and institutional affiliations. 